\title{
Recovering and Identifying Infectious Plant Viruses in Guttation Fluid
}

\author{
Christopher J. French, Maureen Elder, and Frank Skelton \\ Agriculture Canada, Vancouver Research Station, 6660 Northwest Marine \\ Drive, Vancouver, British Columbia V6T 1X2, Canada
}

Additional index words. Gomphrena globosa, green pepper, Capsicum annuum, pepper mild mottle virus, tobamovirus, tomato, Lycopersicon esculentum, tomato mosaic virus

\begin{abstract}
Tomato mosaic virus (ToMV) virions were recovered from guttation fluid of systemically infected tomato (Lycopersicon esculentum Mill.) and visualized by electron microscopy. Similarly, pepper mild mottle virus (PMMV) particles were identified in gattation fluid of systemically infected green pepper (Capsicum annuum L.). Infectivity of ToMV and PMMV in guttation fluid samples was demonstrated on local and systemic hosts. As determined by enzyme-linked immunosorbent assay, the concentration of ToMV in tomato guttation fluid was $0.9 \pm 0.2 \mu \mathrm{g} \cdot \mathrm{ml}^{-1}$ and the concentration of PMMV in green pepper guttation fluid was $0.5 \pm 0.1 \mu \mathrm{g} \cdot \mathrm{ml}^{-1}$. The occurrence of infectious, mechanically transmissible viruses in guttation fluid maybe an important factor in the spread of plant viruses in greenhouse crops.
\end{abstract}

Guttation is a common phenomenon in many plants when conditions are conducive to water uptake and limited transpiration (Burgerstein; 1920); for example, in warm soils and high humidity in the dark. Among field crops, cereals and crucifers are particularly susceptible to guttation (Tiffin, 1972). Under greenhouse conditions, guttation is frequent in cucumber (Cucumis sativus L.) (Yarwood, 1978) and also occurs in tomato (Tal and Gavish, 1973) and green pepper (unpublished data).

Mechanically transmitted tobamoviruses, such as tomato mosaic virus (ToMV) (in tomato) and pepper mild mottle virus (PMMV) (in green pepper) (Greenleaf et al., 1964), often are -found in greenhouse crop plants.

\footnotetext{
Received for publication 12 June 1992. Accepted for publication 8 Feb. 1993. The cost of publishing this paper was defrayed in part by the payment of page charges. Under postal regulations, this paper therefore must be hereby marked advertisement solely to indicate this fact.
}

During a study on the systemic spread of ToMV in globe amaranth (Gomphrena globosa L.), we found virus particles in guttation fluid collected from leaf margins. This prompted an investigation to determine whether infectious virus particles could be isolated from the guttation fluid of other plants infected with tobamoviruses.

'Starfire' tomato plants were inoculated with ToMV (L strain) and 'California Wonder' green pepper with PMMV. Viruses and antisera were obtained from Vancouver Research Station collections. ToMV was purified (Gooding and Hebert, 1967) and diluted to $10 \mu \mathrm{g} \cdot \mathrm{ml}^{-1}$ in $10 \mathrm{~mm}$ sodium phosphate buffer, $\mathrm{pH}$ 7.2. PMMV was transmitted to green pepper test plants by grinding infected leaves in the same buffer. Three- to 4-weekold tomato plants were inoculated mechanically on the first and second true leaves, using carborundum as an abrasive. Four- to 5-weekold pepper plants were inoculated similarly on the third and fourth true leaves. Control plants were mock-inoculated with buffer and abra- sive only. For each virus, there were three plants per treatment, and each experiment was conducted five times. After being mechanically inoculated, plants were grown in a growth room $(22 \pm 2 \mathrm{C}$, 16-h photoperiod, 140 $\mu \mathrm{mol} \cdot \mathrm{m}^{-2} \cdot \mathrm{s}^{-1}$ irradiance) for 3 weeks to induce systemic infection. Infected and control plants were placed in a wood-frame box with clear, $0.1-\mathrm{mm}$ polyethylene walls, and the whole assembly was installed in a growth chamber. The floor of the box was lined with wet paper towels, and the relative humidity in the guttation chamber was $>90 \%$. Guttation was observed under the following conditions: tomato, 12-h photoperiod and $27 \mathrm{C}$ day/15C night; green pepper, 16-h photoperiod and $31 \mathrm{C}$ day/ $20 \mathrm{C}$ night. Guttation fluid drops were collected in capillary tubes from the margins of systemically infected leaves at the start of the

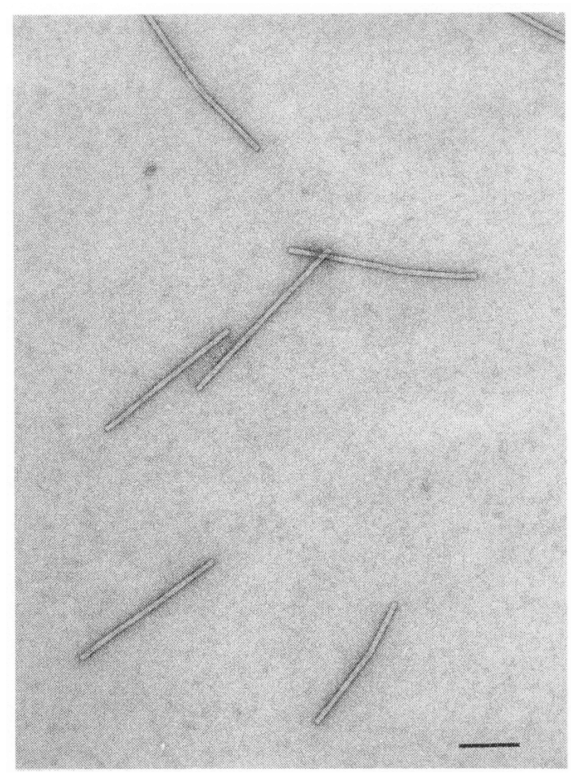

Fig. 1. Pepper mild mottle virus particles recovered from guttation fluid visualized by transmission electron microscopy after negative staining with uranyl acetate. End-to-end aggregation of particles is evident. $\mathrm{Bar}=200 \mathrm{~nm}$. 
photoperiod. Drops were combined to produce a single sample per plant. A $10-\mu \mathrm{ml}$ sample was examined by transmission electron microscopy (model H7000; Hitachi, Rexdale, Ont., Canada) using carbon-coated, collodion copper grids and negative staining with uranyl acetate. For both viruses, rigid 300-nm-long $\times 18$-nm-diameter rods, typical of tobamoviruses (Gibbs, 1977), were observed. PMMV particles recovered from guttation fluid showed end-to-end aggregation, possibly due to a high virus concentration in the plant (Fig. 1). To test whether the particles were infectious, a $50-\mu l$ aliquot of guttation fluid was inoculated mechanically onto the following local lesion hosts: ToMV, Nicotiana glutinosa L. and N. tabacum L. 'Xanthinc' (Hollings and Huttinga, 1976); PMMV, $N$. tabacum 'White Burley' (Wetter and Conti, 1988). Local lesions developed on the test plants at $22 \mathrm{C}$, a result indicating that the guttation fluid was infectious. As a further check on infectivity, a 50- $\mu$ l aliquot of guttation fluid was inoculated onto systemic hosts as follows: ToMV, Lycopersicon esculentum 'Starfire' and N. tabacum 'Harrownova'; PMMV, C. annuum 'California Wonder'. All test plants became systemically infected within 2 weeks, as judged by symptom development and confirmed by enzyme-linked immunosorbent assay (ELISA) (Lommel et al., 1982). In three experiments, the virus concentration in guttation fluid was determined on duplicate $50-\mu \mathrm{l}$ samples by quantitative ELISA (Lommel et al., 1982). ToMV and PMMV virus concentrations were $0.9 \pm 0.2$ and $0.5 \pm 0.1 \mu \mathrm{g} \cdot \mathrm{ml}^{-1}$, respectively. Guttation fluid from all control plants (mock-inoculated) contained no virus particles and gave negative infectivity and ELISA results.

For both viruses, all guttation fluid samples recovered from virus-infected plants contained infectious particles, a result indicating that infectious, mechanically transmissible viruses can be isolated readily from tomato and green pepper guttation fluids. The concentration of virus particles in guttation fluid is sufficient to permit efficient virus transmission to healthy plants. Therefore, it is possible that guttation fluid from systemically infected plants could be a source of inoculum for mechanically transmitted viruses under agricultural conditions. For example, PMMV can cause severe disease in green pepper, during which leaf symptoms are mild and easily overlooked. Most PMMV crop infections are not detected until severe symptoms appear on the fruit, and late diagnosis increases economic loss to growers. Recognizing that viruses may spread via guttation fluid may encourage growers to grow crops under conditions that inhibit guttation; for example, reduced aerial humidity at night. Since leaf surfaces of infected plants become contaminated with infectious particles after guttation, extra precautions to prevent mechanical transmission should be considered.

To our knowledge, only two brief reports on recovering infectious virus particles from natural guttation fluid exist (Johnson, 1937; Ohmam-Kreutzberg et al., 1960), and guttation as a possible means of ToMV spread was not mentioned in one review (Broadbent, 1976). However, our results suggest that guttation fluid from infected plants could be an overlooked means of spreading mechanically transmitted plant viruses in greenhouse crops. The connection between guttation and potential virus spread under field conditions has yet to be made.

\section{Literature Cited}

Burgerstein, A. 1920. Die transpiration der pflanzen II. Fischer, Jena.
Broadbent, K. 1976. Epidemiology and control of tomato mosaic virus. Annu. Rev. Phytopathol. 14:75-96.

Gibbs, A.J. 1977. Tobamovirus group, no. 184. In: Descriptions of plant viruses. Cmwlth. Mycol. Inst.-Assn. Applied Biol., Kew, England.

Gooding, G.V. and T.T. Hebert. 1967. A simple technique for purification of tobacco mosaic virus in large quantities. Phytopathology 57:1285,

Greenleaf, W. H., A.A. Cook, and A.N.J. Heyn. 1964. Resistance to tobacco mosaic virus in Capsicum, with reference to the Samsun Latent strain. Phytopathology 54:1367-1371.

Hollings, M. and H. Huttinga. 1976. Tomato mosaic virus, no, 156. In. Descriptions of plant viruses. Cmwlth. Mycol. Inst.-Assn. Applied Biol., Kew, England.

Johnson, J. 1937. Factors relating to the control of ordinary tobacco mosaic virus. J. Agr. Res. 54:239-273.

Lommel, S.A., A.H. McCain, and T.J. Morris. 1982 Evaluation of indirect enzyme-linked immunosorbent assay for the detection of plant viruses. Phytopathology 72:1018-1022.

Ohmann-Kreutzberg, G., W. Pawlitschek, and H.B Schmidt. 1960. Eigenschaften des weidelgrasmosik-virus. Phytopathol. Z. 38:13-17.

Tal, M. and U. Gavish. 1973. Salt tolerance in the wild relatives of the cultivated tomato: Water balance and absiscic acid in Lycopersicon esculentum and $L$. peruvianum under low and high salinity conditions. Austral. J. Agr. Res. 24:353-361.

Tiffin, L.O. 1972. Translocation of micronutrients in plants, p. 199-229. In: J.J. Mortvedt, P.M. Giordano, and W.L. Lindsay (eds.). Micronutrients in agriculture. Soil Sci. Soc. Amer., Madison, Wis.

Wetter, C. and M. Conti. 1988. Pepper mild mottle virus, no 330. In: Descriptions of plant viruses. Cmwlth. Mycol. Inst.-Assn. Applied Biol., Kew, England.

Yarwood, C.E. 1978. Water and the infection process, p. 141-173. In: T.T. Kozlowski (ed.). Water deficits and plant growth. vol. 5. Academic, New York. 